International Business and Global Economy 2017, no. 36, pp. 171-182

Biznes międzynarodowy w gospodarce globalnej 2017, nr 36, s. 171-182

Edited by the Institute of International Business, University of Gdańsk

ISSN 2300-6102

e-ISSN 2353-9496

DOI 10.4467/23539496IB.17.012.7460

Jarosław Wołkonowski

Uniwersytet w Białymstoku

Wydział Ekonomiczno-Informatyczny w Wilnie

\title{
Litwa w strefie euro. Proces wejścia i skutki inflacyjne wprowadzenia nowej waluty
}

Celem artykułu jest zbadanie procesu wstąpienia Litwy do eurostrefy w 2015 r. oraz inflacji po wprowadzeniu euro. Dane statystyczne odnośnie wielkości inflacji w latach 2015-2016 nie dawały powodów do niepokoju, jednak ceny na poszczególne towary odnotowały w tym okresie wzrost, co wywołało duże niezadowolenie mieszkańców Litwy. W artykule przeanalizowano inflację oraz zmiany cen na poszczególne dobra (m.in. dla 40 najczęściej kupowanych produktów). W analizie zastosowano metodę porównawczą oraz zbadano zmiany wag, obliczając średnioroczne stopy zmian dla klas towarów w zharmonizowanym indeksie cen (HICP) i wykorzystując dane statystyczne Eurostatu, Departamentu Statystyki Litwy, Banku Światowego i Europejskiego Banku Centralnego z lat 2013-2016. Na podstawie przeprowadzonej analizy stwierdzono, że po wprowadzeniu euro nastąpił wzrost cen na poszczególne towary i usługi, jednak spadek cen ropy naftowej na rynkach światowych zniwelował te wzrosty w koszyku, dlatego też inflacja pozostała na niskim poziomie.

Słowa kluczowe: poziom cen, Litwa, euro, inflacja, ekonomia konsumencka

Klasyfikacja JEL: E31, P44, P46

\section{Lithuania in the eurozone: Accession process and inflationary results of introducing new currency}

The aim of the article is to examine the process of Lithuania's accession to the eurozone in 2015 and the inflation resulting from the introduction of the euro. Statistical data for the years 2015-2016 did not give cause for concern, but prices for particular goods increased significantly during this period, which caused great dissatisfaction among the Lithuanians. The paper analyses inflation trends and changes in prices for particular goods (including top 40 most purchased products). The comparative method has been used and weight changes have been measured by calculating the annual rates of change for commodity classes in the Harmonized Index of Consumer Prices (HICP) using 2013-2016 data provided by Eurostat, the Lithuanian Statistics Department, the World Bank, and the European Central Bank. The analysis revealed that after the introduction of the euro the prices for particular goods and services increased, but the decline in oil prices in the world markets offset those increases in the basket, thus maintaining inflation at a low level.

Keywords: price level, Lithuania, euro, inflation, consumer economics

JEL classification: E31, P44, P46 


\section{Wprowadzenie}

1 stycznia 2015 r. Litwa weszła do strefy euro. Kraj ten po transformacji systemowej w $1990 \mathrm{r}$. na przełomie wieków XX i XXI przeszedł skomplikowaną drogę wprowadzenia swojej waluty narodowej (lit) i wyjścia z sowieckiego systemu gospodarczego i finansowego. Zaowocowało to wstąpieniem wiosną 2004 r. do NATO i Unii Europejskiej. W atmosferze tych sukcesów w latach 2005-2007 Litwa podjęła ambitny plan wejścia do strefy euro z dniem 1 stycznia 2007 r., próba ta okazała się jednak nieudana. Kolejną podjęto osiem lat później i 1 stycznia 2015 r. Litwa znalazła się w eurostrefie. Wprowadzenie nowej waluty odbyło się praktycznie bez większych problemów.

Pierwsze informacje dotyczące inflacji za lata 2015 i 2016 były optymistyczne dane statystyczne Eurostatu i Departamentu Statystyki Litwy pokazywały inflację około $1 \%$, a w poszczególnych miesiącach wskazywały nawet na deflację. Przed wprowadzeniem euro rząd Litwy przyjął stosowne akty prawne, by ceny wszystkich produktów będących w sprzedaży pół roku przed wprowadzeniem euro i pół roku po jego wprowadzeniu były podawane w euro i litach - tak chciał się zabezpieczyć przed wzrostem cen wobec nieuczciwych handlarzy. Mimo działań władz Litwy i dobrej koniunktury gospodarczej (spadki światowych cen ropy i gazu) większość mieszkańców Litwy, według przeprowadzonych badań opinii publicznej, była i jest zdania, że po wprowadzeniu euro nastąpił znaczący wzrost cen, najbardziej widoczny w sektorze usług [Dauguma țmonir mano..., 2015; Radom ir palyginom..., 2016].

Celem niniejszego artykułu jest ustalenie przyczyn takiego stanu rzeczy oraz zbadanie i dokonanie analizy wskaźnika inflacji w okresie przed wstąpieniem do strefy euro, jak i w latach po wstąpieniu do niej - w okresie 2015-2016.

\section{Wprowadzenie waluty narodowej na Litwie}

1 lipca 1993 r. Sejm Litwy przyjął ustawę o pieniądzach Republiki Litewskiej, na mocy której jednostką pieniężną na Litwie został lit, który składa się z 100 centów. Wartość tego pieniądza miał określić Bank Litwy [Ustawa, 1993]. W tym okresie władze Litwy przyjęły uchwałę wprowadzającą nową walutę narodową zamiast talonów (czasowy pieniądz na Litwie w latach 1990-1993) według kursu: 1 Lt za 100 talonów [Uchwała, 1993]. W czerwcu 1993 r. po wprowadzeniu lita przez Rząd Litwy i zarząd Banku Litwy [Uchwała, 1993] jego kurs miał wzmacniającą się tendencję (tab. 1), a od kwietnia 1994 r. do lutego 2002 r. Bank Litwy ustalił sztywny kurs 4,0 Lt za 1 USD [Kurs, 1994]. 29 września 1994 r. uchwałą 
zarządu Banku Litwy bazową walutą lita został dolar amerykański według oficjalnego sztywnego kursu 0,25 USD za 1 Lt [Uchwała, 1994].

Tabela 1. Kurs lita do dolara amerykańskiego na Litwie w latach 1993-1994

\begin{tabular}{|l|c|c|c|c|c|c|c|c|c|c|}
\hline & \multicolumn{10}{|c|}{ Miesiąc i rok } \\
\cline { 2 - 10 } & 6.1993 & 7.1993 & 8.1993 & 9.1993 & 10.1993 & 11.1993 & 12.1993 & 1.1994 & 2.1994 & 3.1994 \\
\hline $\begin{array}{l}\text { Kurs } \\
\text { lita do } \\
\text { USD }\end{array}$ & 4,500 & 4,300 & 4,014 & 4,179 & 4,105 & 3,940 & 3,913 & 3,9001 & 3,904 & 3,929 \\
\hline
\end{tabular}

Źródło: [Miesięczny stosunek lita..., 1993].

2 lutego 2002 r. uchwałą zarządu Banku Litwy bazową walutą lita zostało euro według oficjalnego kursu 3,4528 Lt za 1 EUR [Uchwała, 2002]. Przyjmując sztywny kurs lita - najpierw do USD, a później do euro - rząd Litwy chciał się zabezpieczyć przed atakami spekulantów na walutę narodową.

\section{Nieudana próba wprowadzenia euro na Litwie w 2007 r.}

29 września 2005 r. rząd Litwy przyjął program wprowadzenia euro od 1 stycznia 2007 r. [Uchwała, 2005]. Próba ta okazała się jednak nieudana na skutek niespełnienia jednego z warunków konwergencji, a mianowicie stopy inflacji, określanej jako procentowa zmiana ogólnego poziomu cen w kolejnych okresach [Hall, Taylor, 2009; Marciniak, 2013]. Zgodnie z opinią Komisji Europejskiej: „W marcu 2006 r. wartość referencyjna - liczona jako średnia stopy inflacji w skali 12 miesięcy w trzech państwach członkowskich o najlepszych wynikach (Szwecja, Finlandia, Polska) plus 1,5 punktów procentowych - wynosiła 2,6\%. Odpowiednia stopa inflacji na Litwie wynosiła $2,7 \%$, nieco powyżej wartości referencyjnej”. Komisja odnotowała wzrostowy trend inflacji na najbliższą przyszłość. W swym końcowym wniosku Komisja Europejska 16 maja 2006 r. stwierdziła: „Na dzień dzisiejszy Litwa nie spełnia kryterium stabilności cen. [...] Komisja stwierdza, że nie należy zmieniać statusu Litwy «jako państwa członkowskiego objętego derogacją»" [Sprawozdanie, 2006].

W okresie 2005-2007 inflacja na Litwie (tab. 2) miała tendencję wzrostową: w 2006 r. - 3,7\%, w 2007 r. - 5,7\%, w 2008 r. - 10,9\%. Biorąc pod uwagę powyższe dane, należy obiektywnie stwierdzić, że negatywna decyzja władz UE była słuszna (mimo przekroczenia wymaganej wielkości zaledwie o 0,1 p.p.), gdyż Litwa nie spełniła wymagań. Co więcej, przewidywania KE o wzroście inflacji również okazały się trafne - w okresie 2006-2008 na Litwie nastąpił wzrost inflacji, która w 2008 r. osiągnęła wartość dwucyfrową. 
Tabela 2. Średnioroczna inflacja na Litwie w latach 2004-2010

\begin{tabular}{|l|l|l|l|l|l|l|l|l|}
\hline \multirow{2}{*}{\multicolumn{1}{c|}{ Wielkość inflacji }} & \multicolumn{7}{c|}{ Rok } \\
\cline { 2 - 11 } & 2003 & 2004 & 2005 & 2006 & 2007 & 2008 & 2009 & 2010 \\
\hline Departament Statystyki Litwy & $-1,1$ & 1,2 & 2,7 & 3,7 & 5,7 & 10,9 & 4,5 & 1,3 \\
\hline Eurostat & $-1,1$ & 1,2 & 2,7 & 3,8 & 5,8 & 11,1 & 4,2 & 1,2 \\
\hline Bank Światowy & $-1,15$ & 1,18 & 2,64 & 3,75 & 5,73 & 10,93 & 4,44 & 1,33 \\
\hline Europejski Bank Centralny & $-1,08$ & 1,17 & 2,68 & 3,76 & 5,78 & 11,13 & 4,23 & 1,20 \\
\hline
\end{tabular}

Źródło: [Statistical Yearbook..., 2011, s. 333; Eurostat, 2010; World Bank, 2010; ECB, 2010].

\section{Wprowadzenie euro na Litwie w 2015 r.}

Kolejną próbę przyjęcia euro władze Litwy podjęły w 2012 r. W programie rządu Litwy z 13 grudnia 2012 r. wpisano (p. 34), że działania mające na celu wprowadzenie euro zostaną podjęte, jak tylko Litwa spełni wymagane warunki [Uchwała, 2012]. Na tej podstawie 26 czerwca 2013 r. rząd Litwy podjął uchwałę o szczegółowym planie wprowadzenia euro [Uchwała, 2013]. Po przeprowadzeniu niezbędnych prac organizacyjnych 17 kwietnia 2014 r. Sejm Litwy przyjął ustawę o wprowadzeniu euro z dniem 1 stycznia 2015 r. [Ustawa, 2014]. 23 lipca 2014 r. Rada Ministrów Unii Europejskiej stwierdziła, że tym razem Litwa spełnia kryteria konwergencji (średnia stopa inflacji do kwietnia 2014 r. wyniosła 0,6\%) i podjęła pozytywną decyzję o przystąpieniu Litwy do eurostrefy z dniem 1 stycznia 2015 r. [Decyzja, 2014].

$\mathrm{W}$ tabeli 3 przedstawiono podaż pieniądza na koniec grudnia $\mathrm{w}$ latach 2007-2015 oraz inflację i zmianę PKB do roku poprzedniego. Widzimy, że podaż pieniądza praktycznie każdego roku rosła i średnioroczny wzrost $\mathrm{w}$ okresie 1993-2013 wynosił 13,8\%. Dane na temat podaży pieniądza w obiegu z grudnia 2014 r. są obciążone przygotowaniem się do wymiany na euro i wycofaniem dużej podaży pieniądza z obiegu zgodnie z planem wprowadzenia euro [Uchwała, 2013, p. 72]. Na 1 stycznia 2015 r. nastąpił znaczny wzrost podaży pieniądza, jednak już pod koniec tego roku odnotowano jej znaczący spadek - do 5,96 mld EUR (o 16,1\%) [Statistical Yearbook..., 2016, s. 566].

Wprowadzenie euro na Litwie odbyło się praktycznie bez większych problemów. Rząd Litwy uchwalił stosowne akty prawne, by wszystkie produkty będące w sprzedaży po 60 dniach od wydania przez Radę Ministrów Unii Europejskiej zgody na wprowadzenie euro i pół roku po jego wprowadzeniu były podawane zarówno w euro, jak i w litach - tak chciał się on zabezpieczyć przed wzrostem cen wobec nieuczciwych handlarzy [Uchwała, 2013, p. 20]. Mimo takich działań władz Litwy i dobrej koniunktury gospodarczej (spadki światowych cen ropy 
i gazu w okresie 2014-2016) większość mieszkańców Litwy, według przeprowadzonych badań opinii publicznej, była zdania, że po wprowadzeniu euro nastąpił wzrost cen, najbardziej widoczny w sektorze usług [Dauguma tmoniř mano..., 2015; Radom ir palyginom..., 2016].

Tabela 3. Podaż pieniądza na koniec roku na Litwie w latach 2007-2015

\begin{tabular}{|c|c|c|c|c|c|}
\hline \multirow[t]{2}{*}{ Rok } & \multirow{2}{*}{$\begin{array}{l}\text { Banknoty } \\
\text { i monety } \\
\text { w obiegu }\end{array}$} & $\begin{array}{c}\text { Zmiana } \\
\text { podaży } \\
\text { pieniądza }\end{array}$ & Inflacja & $\begin{array}{c}\text { Zmiana PKB } \\
\text { do roku po- } \\
\text { przedniego }\end{array}$ & \multirow[t]{2}{*}{ Kurs Lt do EUR } \\
\hline & & \multicolumn{3}{|c|}{$(\%)$} & \\
\hline 31.12 .2007 & 8,105 mld Lt & 11,9 & 5,7 & 20,60 & 3,4528 Lt za 1 EUR \\
\hline 31.12.2008 & $8,520 \mathrm{mld} \mathrm{Lt}$ & 5,1 & 10,9 & 12,59 & 3,4528 Lt za 1 EUR \\
\hline 31.12.2009 & 7,932 mld Lt & $-6,9$ & 4,5 & $-17,62$ & 3,4528 Lt za 1 EUR \\
\hline 31.12 .2010 & $8,824 \mathrm{mld} \mathrm{Lt}$ & 11,2 & 1,3 & 4,06 & 3,4528 Lt za 1 EUR \\
\hline 31.12 .2011 & 10,827 mld Lt & 22,7 & 4,1 & 11,59 & 3,4528 Lt za 1 EUR \\
\hline 31.12.2012 & 11,417 mld Lt & 5,4 & 3,1 & 6,63 & 3,4528 Lt za 1 EUR \\
\hline 31.12 .2013 & 11,902 mld Lt & 4,2 & 1,0 & 4,96 & 3,4528 Lt za 1 EUR \\
\hline 31.12.2014 & $5,762 \mathrm{mld} \mathrm{Lt}^{*}$ & $-51,6$ & 0,1 & 4,54 & 3,4528 Lt za 1 EUR \\
\hline $01.01 .2015^{* *}$ & 7,105 mld EUR & 325,7 & - & - & wprowadzenie EUR \\
\hline 31.12 .2015 & 5,960 mld EUR & $-16,1$ & $-0,9$ & 2,02 & - \\
\hline
\end{tabular}

* Zmniejszenie się podaży pieniądza wynikało z planu wprowadzenia euro [Uchwała, 2013, p. 72].

** Na dzień 1 stycznia 2015 r. zostały dokonane przeliczenia w związku z przeklasyfikowaniem i operacjami związanymi z uczestnictwem w eurosystemie [Statistical Yearbook..., 2016, s. 566].

Źródło: Obliczenia własne na podstawie: [Statistical Yearbook..., 2008, s. 498; Statistical Yearbook..., 2010, s. 489; Statistical Yearbook..., 2011, s. 490; Statistical Yearbook..., 2013, s. 530; Statistical Yearbook..., 2014, s. 543; Statistical Yearbook..., 2015, s. 556; Statistical Yearbook..., 2016, s. 567; Economic and Social Development..., 2009, s. 9].

\section{Inflacja na Litwie w okresie przyjęcia euro}

Litwa prowadzi badania nad inflacją według agregatowego indeksu cen zgodnie z formułą Laspeyresa, który pokazuje zmianę cen konsumpcyjnych produktów w badanym okresie w porównaniu z okresem bazowym, zakładając, że wielkość spożycia w obu okresach jest taka sama [Eurostat, 2016c, s. 10]. Metodyka obliczania inflacji jest zgodna $\mathrm{z}$ aktami prawnymi przyjętymi $\mathrm{w}$ tej kwestii przez Unię Europejską - dlatego indeks nazwano zharmonizowanym. Dane statystyczne na temat wskaźników związanych z inflacją przygotowuje Departament Statystyki Litwy i zamieszcza na swojej stronie. Dane te są co miesiąc przekazywane do Eurostatu, gdzie na ich podstawie tworzony jest COICOP/HICP (Classification of Individual Consumption by Purpose - COICOP, Harmonised Index of Consumer 
Prices - HICP). Zgodnie z traktatem z Maastricht wskaźnik HICP jest podstawą do oceny zmiany cen w krajach UE. Każdego miesiąca kraje UE obserwują zmiany cen około 900 różnych produktów i usług. Obliczenia są oparte na wersji Klasyfikatora Spożycia Indywidualnego według celu COICOP opracowanego przez ONZ w 1999 r. [Eurostat, 2016c, s. 4].

Tabela 4. Średnioroczna inflacja na Litwie w latach 2011-2016

\begin{tabular}{|l|l|l|l|l|l|l|}
\hline \multirow{2}{*}{\multicolumn{1}{c|}{ Wielkość inflacji }} & \multicolumn{7}{c|}{ Rok } \\
\cline { 2 - 8 } & 2011 & 2012 & 2013 & 2014 & 2015 & 2016 \\
\hline Departament Statystyki & 4,1 & 3,1 & 1,0 & 0,1 & $-0,9$ & 1,0 \\
\hline Eurostat & 4,1 & 3,2 & 1,2 & 0,2 & $-0,7$ & 0,7 \\
\hline Bank Światowy & 4,13 & 3,09 & 1,05 & 0,11 & $-0,88$ & 1,18 \\
\hline Europejski Centralny Bank & 4,13 & 3,15 & 1,17 & 0,30 & $-0,64$ & 0,69 \\
\hline
\end{tabular}

Źródło: [Statistical Yearbook..., 2016, s. 438; Eurostat, 2016c; World Bank, 2016; obliczenia własne na podstawie: ECB, 2016].

Po przeanalizowania inflacji na Litwie (tab. 4) w okresie przed wprowadzeniem euro i po jego wprowadzeniu widzimy, że wskaźnik ten na Litwie w latach 2013-2014 utrzymywał się na niskim poziomie. Po przyjęciu euro w roku 2015 nastąpiła deflacja, a w $2016 \mathrm{r}$. inflacja pozostawała w granicach $0,7-1,18 \%$, co jest wynikiem bardzo dobrym.

Bardzo ważnym czynnikiem w obliczeniu inflacji są wagi towarów konsumpcyjnych - system wag opiera się na strukturze spożycia indywidualnego w sektorze gospodarstw domowych ze statystyki rachunków narodowych sprzed dwóch lat. Rola tego czynnika wynika z zasady, że konsumenci kupują różne dobra $\mathrm{z}$ różną częstotliwością. Wagi mogą być mierzone w procentach lub w promilach.

$\mathrm{W}$ tabeli 5 podano wagi grup indeksowanych cen konsumpcyjnych na Litwie dla okresu 2013-2016. W ostatniej kolumnie tej tabeli zostały policzone średnioroczne stopy zmian wag konsumpcyjnych grup towarów. Jak widzimy, znaczne wzrosty średniorocznych stóp odnotowały grupy: 3. Ubranie i obuwie $(8,4 \%)$; 5. Wyposażenie mieszkania, meble $i$ prowadzenie gospodarstwa domowego $(9,6 \%)$; 7. Transport (2,1\%); 9. Odpoczynek i kultura (13,7\%); 12. Różne towary i usługi (20,3\%). Spadki wag odnotowały następujące klasy: 1. Żywność $i$ napoje niealkoholowe $(-5,4 \%)$; 4. Mieszkanie, woda, elektryczność, gaz i inne paliwo (-7,9\%); 8. Łączność $(-5,7 \%)$; 10. Oświata $(-9,1 \%)$ i 11. Restauracje i hotele $(-13,3 \%)$. Korekty wag dokonywane przez Departament Statystyki Litwy opierały się na zasadzie, że w miarę wzrostu dobrobytu udziały grup towarów pierwszej potrzeby zmniejszają się, a wzrastają udziały grup towarów wyższego rzędu. 
Tabela 5. Wagi grup towarów na Litwie w latach 2013-2016 i średnioroczna stopa zmian $(\mathrm{w} \%)$

\begin{tabular}{|l|r|r|r|r|c|}
\hline \multirow{2}{*}{ Grupa towarów lub usług } & \multicolumn{5}{c|}{ Rok } \\
\cline { 2 - 6 } & 2013 & 2014 & 2015 & 2016 & $\Delta r$ \\
\hline 1. Żywność i napoje niealkoholowe (74 podkl.) & 252,8 & 236,9 & 217,5 & 214,4 & $-5,4$ \\
\hline 2. Napoje alkoholowe, tytoń (18 podkl.) & 89,2 & 85,6 & 84,4 & 86,0 & $-1,2$ \\
\hline 3. Ubranie i obuwie (18 podkl.) & 60,0 & 67,1 & 66,5 & 76,4 & 8,4 \\
\hline $\begin{array}{l}\text { 4. Mieszkanie, woda, elektryczność, gaz, } \\
\text { inne paliwo (32 podkl.) }\end{array}$ & 132,5 & 123,4 & 120,8 & 103,3 & $-7,9$ \\
\hline $\begin{array}{l}\text { 5. Wyposażenie mieszkania, meble i prowadzenie } \\
\text { gospodarstwa domowego (55 podkl.) }\end{array}$ & 53,3 & 61,9 & 62,8 & 70,3 & 9,6 \\
\hline 6. Zdrowie (22 podkl.) & 61,1 & 53,5 & 63,2 & 65,1 & 2,1 \\
\hline 7. Transport (41 podkl.) & 134,4 & 147,3 & 153,1 & 143,1 & 2,1 \\
\hline 8. Łączność (15 podkl.) & 34,4 & 25,6 & 27,5 & 28,8 & $-5,7$ \\
\hline 9. Odpoczynek i kultura (76 podkl.) & 51,8 & 68,8 & 69,9 & 76,1 & 13,7 \\
\hline 10. Oświata (7 podkl.) & 17,3 & 12,1 & 12,3 & 13,0 & $-9,1$ \\
\hline 11. Restauracje i hotele (9 podkl.) & 67,6 & 51,9 & 43,4 & 44,0 & $-13,3$ \\
\hline 12. Różne towary i usługi (43 podkl.) & 45,7 & 65,9 & 78,6 & 79,5 & 20,3 \\
\hline Razem (410 podkl.) & 1000 & 1000 & 1000 & 1000 & 0,0 \\
\hline
\end{tabular}

Źródło: Obliczenia własne na podstawie: [Departament, 2016a; Eurostat, 2016b].

Wszystkie towary konsumpcyjne zostały podzielone na 12 klas, z których każda obejmuje podklasy - najwięcej podklas zawierają grupy: 9. Odpoczynek i kultura (76), 1. Żywność i napoje niealkoholowe (74), 5. Wyposażenie mieszkania, meble i prowadzenie gospodarstwa domowego (55), 12. Różne towary i usługi (43), 7. Transport (41). Ogólem w 12 klasach znajduje się 410 podklas.

$\mathrm{W}$ tabeli 6 podano indeksy cen konsumpcyjnych odnotowywane na grudzień dla lat 2013-2016 w porównaniu z rokiem 2015 oraz roczną stopę zmian.

Analizując zmiany indeksów grup towarów oraz roczne stopy zmian, widzimy, że roczna stopa wzrostu dla wszystkich grup wynosiła w badanym okresie 0,5\%. Należy jednak odnotować spadki tego wskaźnika w latach 2014 i 2015 oraz jego wzrost dla roku 2016 do wysokości 1,9\%. Dwie bardzo ważne klasy: 1. Żywność i napoje niealkoholowe oraz 3. Ubranie i obuwie miały w badanym okresie stopy wzrostu $1 \%$. Znaczne stopy wzrostu odnotowały grupy: 2. Napoje alkoholowe i tyton (2,9\%); 6. Zdrowie (2,2\%); 9. Odpoczynek i kultura (1,5\%); 10. Oświata $(2,5 \%) ; 11$. Restauracje $i$ hotele $(4,6 \%)$; 12. Różne towary ustugi $(2,4 \%)$. Spadki indeksów odnotowały następujące klasy: 4. Mieszkanie, woda, elektryczność, gaz $i$ inne paliwo $(-2,7 \%)$; 7. Transport $(-3,0 \%)$; 8. Eq̨czność $(-3,0 \%)$. 
Tabela 6. Roczne indeksy cen konsumpcyjnych $(2015=100)$ w grudniu dla lat 2013-2016 i średnioroczna stopa zmian (w \%)

\begin{tabular}{|l|r|r|r|r|c|}
\hline \multirow{2}{*}{ Grupa towarów lub usług } & \multicolumn{5}{c|}{ Rok } \\
\cline { 2 - 6 } & 2013 & 2014 & 2015 & 2016 & $\Delta r$ \\
\hline 1. Żywność i napoje niealkoholowe & 99,60 & 99,66 & 99,16 & 102,74 & 1,0 \\
\hline 2. Napoje alkoholowe, tytoń & 95,25 & 99,28 & 99,62 & 103,91 & 2,9 \\
\hline 3. Ubranie i obuwie & 102,64 & 103,02 & 106,14 & 105,75 & 1,0 \\
\hline $\begin{array}{l}\text { 4. Mieszkanie, woda, elektryczność, gaz } \\
\text { i inne paliwo }\end{array}$ & 103,96 & 103,69 & 100,2 & 97,78 & $-2,0$ \\
\hline $\begin{array}{l}\text { 5. Wyposażenie mieszkania, meble i prowadzenie } \\
\text { gospodarstwa domowego }\end{array}$ & 98,58 & 98,49 & 100,6 & 101,57 & 1,0 \\
\hline 6. Zdrowie & 96,29 & 97,88 & 101,08 & 102,64 & 2,2 \\
\hline 7. Transport & 108,62 & 102,6 & 96,19 & 99,26 & $-3,0$ \\
\hline 8. Łączność & 102,98 & 99,87 & 100,25 & 94,04 & $-3,0$ \\
\hline 9. Odpoczynek i kultura & 97,70 & 98,14 & 100,56 & 102,27 & 1,5 \\
\hline 10. Oświata & 97,59 & 98,80 & 101,74 & 105,02 & 2,5 \\
\hline 11. Restauracje i hotele & 93,63 & 96,68 & 101,48 & 107,17 & 4,6 \\
\hline 12. Różne towary i usługi & 96,85 & 98,61 & 101,30 & 104,14 & 2,4 \\
\hline Razem & 100,34 & 100,23 & 99,98 & 101,94 & 0,5 \\
\hline
\end{tabular}

Źródło: Obliczenia własne na podstawie: [Departament, 2016b].

\section{Szczegółowe badania inflacji na Litwie w latach 2015-2016}

W celu bardziej szczegółowego monitoringu nad procesem kształtowania się cen Departament Statystyki Litwy prowadzi miesięczne badania zmian cen dla najczęściej kupowanych towarów i usług - grupa ta obejmuje łącznie 40 dóbr (udział ich stanowi w 2015 r. 18,57\% od ogółu): 32 artykuły spożywcze (10,55\% od ogółu), 6 produktów przetwórstwa przemysłowego (6,67\% od ogółu) i 2 usługi (1,35\% od ogółu). Dane za lata 2015-2016 zawarto w tabelach 7 i 8.

$\mathrm{Z}$ danych przedstawionych $\mathrm{w}$ tabeli 7 widzimy, że w grupie 40 najczęściej używanych produktów nastąpily w roku 2015 spadki w porównaniu z grudniem 2014 r. Dotyczy to także pozostałych produktów konsumpcyjnych. Niskie ceny na benzynę A-95, której udział jest bardzo znaczący (3,49\% w grupie towarów o udziale $18,57 \%$ ogółu), spowodował, że grupa ta miała zniżkową tendencję w porównaniu z grudniem 2014 r. Spadek cen na benzynę wynikał z ogólnego trendu światowego w tym okresie. Tymczasem w grupie najczęściej używanych produktów ceny na poszczególne produkty miały inną tendencję - na przykład jabłka, które odnotowały znaczące wzrosty (udział tego produktu wynosił jednak zaledwie 0,14\% w koszyku konsumpcyjnym). Spadek cen produktów mlecznych 
(m.in. twarogu) wynikał z sankcji gospodarczych Rosji, która zamknęła swój rynek dla produktów mlecznych z Litwy. Spowodowało to zwiększoną podaż produktów mlecznych na rynek litewski i spadki cen [Wołkonowski, 2016].

Tabela 7. Zmiany cen grup towarów najczęściej używanych w 2015 r. w porównaniu z grudniem 2014 r. (w \%)

\begin{tabular}{|l|c|c|c|c|c|c|c|c|c|c|c|c|}
\hline \multirow{2}{*}{ Produkt (udział) } & \multicolumn{10}{|c|}{ Miesiąc } \\
\cline { 2 - 14 } & 01. & 02. & 03. & 04. & 05. & 06. & 07. & 08. & 09. & 10. & 11. & 12. \\
\hline $\begin{array}{l}\text { Grupa 40 produk- } \\
\text { tów (18,57\%) }\end{array}$ & $-2,0$ & $-1,9$ & $-0,7$ & 0,0 & 0,7 & 0,6 & 0,0 & $-2,2$ & $-2,2$ & $-1,6$ & $-2,6$ & $-3,0$ \\
\hline $\begin{array}{l}\text { Ogółem produkty } \\
(100 \%)\end{array}$ & $-1,3$ & $-1,6$ & $-0,9$ & $-0,2$ & 0,3 & 0,2 & 0,3 & $-1,1$ & $-0,5$ & 0,0 & 0,3 & $-0,1$ \\
\hline $\begin{array}{l}\text { Benzyna A-95 } \\
(3,49 \%)\end{array}$ & $-11,6$ & $-8,1$ & $-1,1$ & $-0,6$ & 5,7 & 8,1 & 7,6 & 0,5 & $-3,4$ & $-4,5$ & $-9,9$ & $-11,3$ \\
\hline Twaróg (0,56\%) & 0,3 & $-2,5$ & $-6,0$ & $-7,2$ & $-7,4$ & $-8,5$ & $-9,1$ & $-9,6$ & $-8,8$ & $-10,5$ & $-9,6$ & $-10,5$ \\
\hline $\begin{array}{l}\text { Olej rzepakowy } \\
(0,31 \%)\end{array}$ & $-0,4$ & $-3,2$ & $-0,7$ & 0,5 & $-0,6$ & 3,1 & 5,4 & 5,0 & 8,7 & 6,4 & 5,2 & 5,3 \\
\hline Jabłka (0,14\%) & 1,6 & $-0,5$ & $-0,3$ & 13,4 & 25,7 & 39,5 & 41,3 & 40,2 & 33,1 & 20,7 & 14,7 & 15,2 \\
\hline Fryzjer (0,64\%) & 1,4 & 1,8 & 2,1 & 2,7 & 2,9 & 3,1 & 3,4 & 4,2 & 5,0 & 5,5 & 5,6 & 6,1 \\
\hline
\end{tabular}

Źródło: [Departament, 2015].

Tabela 8. Zmiany cen grup towarów najczęściej używanych w 2016 r. w porównaniu z grudniem 2015 r. (w \%)

\begin{tabular}{|l|c|c|c|c|c|c|c|c|c|c|c|c|}
\hline \multirow{2}{*}{ Produkt (udział) } & \multicolumn{10}{|c|}{ Miesiąc } \\
\cline { 2 - 14 } & 01. & 02. & 03. & 04. & 05. & 06. & 07. & 08. & 09. & 10. & 11. & 12. \\
\hline $\begin{array}{l}\text { Grupa 40 produk- } \\
\text { tów (18,44\%) }\end{array}$ & 0,4 & 0,2 & 1,0 & 2,8 & 3,0 & 3,0 & 2,2 & 1,3 & 2,2 & 2,7 & 3,7 & 5,3 \\
\hline $\begin{array}{l}\text { Ogółem produkty } \\
(100 \%)\end{array}$ & $-0,3$ & $-0,7$ & 0,4 & 0,9 & 0,9 & 1,0 & 0,3 & $-0,2$ & 0,4 & 1,1 & 1,3 & 1,7 \\
\hline $\begin{array}{l}\text { Benzyna A-95 } \\
(3,3 \%)\end{array}$ & $-2,7$ & $-3,3$ & $-3,2$ & 0,4 & 2,7 & 4,6 & 2,5 & 0,1 & 2,1 & 4,6 & $-1,0$ & 5,0 \\
\hline Twaróg (0,55\%) & 0,5 & 0,6 & 0,5 & 1,7 & 0,2 & $-0,9$ & $-0,9$ & 0,1 & $-1,6$ & $-3,5$ & 2,0 & 5,7 \\
\hline $\begin{array}{l}\text { Olej rzepakowy } \\
(0,36 \%)\end{array}$ & 1,8 & 5,2 & 5,7 & 5,5 & 6,3 & 7,2 & 4,0 & 5,4 & 7,1 & 7,8 & 4,0 & 6,3 \\
\hline Jabłka (0,14\%) & $-0,3$ & $-2,4$ & $-2,8$ & $-6,4$ & $-6,9$ & $-9,1$ & $-11,0$ & $-10,3$ & $-10,3$ & $-13,7$ & $-14,1$ & $-15,5$ \\
\hline Fryzjer (0,72\%) & 0,6 & 1,6 & 2,0 & 2,3 & 3,5 & 3,6 & 4,4 & 4,6 & 5,3 & 5,7 & 6,0 & 6,3 \\
\hline
\end{tabular}

Źródło: [Departament, 2016c].

W 2016 r. trend cenowy dla grupy najczęściej używanych towarów (40) zmienił się z malejącego na wzrastający. $\mathrm{W}$ drugiej połowie roku zmianie uległ 
trend ceny benzyny A-95, co miało wpływ na ogólne zmiany cen dla grupy towarów najczęściej używanych. Współczynnik korelacji Pearsona pomiędzy zmianą cen produktu A-95 i zmianą cen grupy produktów najczęściej używanych (40) wynosił w 2015 r. 0,86, a w roku 2016 - 0,74 (w obu przypadkach był silnie dodatni). W latach 2015-2016 należy również odnotować stabilny duży wzrost cen w sektorze usług (fryzjer).

\section{Podsumowanie}

W atmosferze sukcesów polityczno-gospodarczych (wstąpienie do NATO i Unii Europejskiej wiosną 2004 r.) Litwa w latach 2005-2006 podjęla ambitny plan wejścia do strefy euro z dniem 1 stycznia 2007 r. Zbliżający się kryzys finansowy oraz braki w prognozowaniu inflacji w polityce monetarnej [Szyszko, 2009; Solow, Taylor, 2002] nie pozwoliły spełnić kryterium konwergencji i Komisja Europejska negatywnie zaopiniowała wniosek Litwy o wstąpienie do strefy euro. W sprawozdaniu Komisji Europejskiej stwierdzono, że średnia stopa inflacji w skali 12 miesięcy w trzech państwach członkowskich o najlepszych wynikach (Szwecja, Finlandia, Polska) plus 1,5 p.p. - wynosiła 2,6\%, na Litwie zaś 2,7\%. Jednocześnie Komisja odnotowała wzrostowy trend inflacji w najbliższej perspektywie, co potwierdziły dane za lata 2007-2008, gdy inflacja na Litwie osiągnęła wartość dwucyfrową.

W latach 2012-2014 Litwa podjęła kolejną próbę wstąpienia do strefy euro. Tym razem rząd Litwy spełnił wszystkie warunki konwergencji (m.in. inflacja roczna 0,6\%) i 1 stycznia 2015 r. w kraju wprowadzono do obiegu banknoty euro. Rząd Litwy podjął niezbędne kroki $\mathrm{w}$ celu przeciwdziałania nadużyciom przed wzrostem cen wobec nieuczciwych handlarzy, tym niemniej w poszczególnych klasach towarów, a przede wszystkim usług, nastąpił wzrost cen, co znalazło potwierdzenie w sondażach analizujących negatywne opinie mieszkańców Litwy na temat wzrostu cen po wprowadzeniu euro. Spadki cen ropy naftowej na światowych rynkach nie pozwoliły na wzrosty ogólnego wskaźnika inflacji na Litwie po wprowadzeniu euro w latach 2015-2016, tym niemniej nie zmieniły pesymistycznej opinii mieszkańców Litwy. Na podstawie przeprowadzonej analizy można stwierdzić, że wprowadzenie nowej waluty na Litwie było nowym otwarciem cenowych relacji gospodarczych na rynku krajowym.

Podziękowania

Autor składa podziękowanie Pani Virginii Jasionienë z Departamentu Statystyki Litwy za udostępnienie materiałów na temat zmian cen towarów i usług najczęściej kupowanych na Litwie w 2015 r. 
Bibliografia

Dauguma țmoniř mano, kad kainos ávedus eurŕ pakilo, 2015 (2015.11.03), http://www.ve.lt/naujienos/ekonomika/euras/dauguma-zmoniu-mano-kad-kainos-ivedus-eura-pakilo1409288/ [dostęp: 17.03.2017].

Decyzja Rady z dnia 23 lipca 2014 r. w sprawie przyjęcia przez Litwę euro w dniu 1 stycznia 2015 r. (2014/509/UE), http://www.lex.pl/serial-akt/-/akt/dz-u-ue-1-2014-228-29 [dostęp: 17.03.2017].

Departament, 2015, Dane na temat zmian cen towarów i usług najczęściej kupowanych w roku 2015.

Departament, 2016a, http://osp.stat.gov.lt/statistiniu-rodikliu-analize?id=11446\&status=A [dostęp: 10.03.2017].

Departament, 2016b, http://osp.stat.gov.lt/statistiniu-rodikliu-analize?id=11445\&status=A [dostęp: 10.03.2017].

Departament, 2016c, http://osp.stat.gov.lt/temines-lenteles38 [dostęp: 10.03.2017].

Economic and Social Development in Lithuania 2009/5, Lietuvos ekonominë ir socialinë raida, 2009, Lietuvos Statistikos Departamentas, Vilnius.

European Central Bank, 2010, http://www.ecb.europa.eu/stats/ecb_statistics/escb/html/table. en.html?id=JDF_ICP_COICOP_ANR\&period=index [dostęp: 10.03.2017].

European Central Bank, 2016, http://www.ecb.europa.eu/stats/ecb_statistics/escb/html/table. en.html?id=JDF_ICP_COICOP_ANR\&period=index [dostęp: 17.03.2017].

Eurostat, 2010, http://ec.europa.eu/eurostat/tgm/table.do?tab=table\&init=1\&language $=$ en\&pcode $=$ tec00118\&plugin $=1 ;$ http://appsso.eurostat.ec.europa.eu/nui/submitViewTableAction.do [dostęp: 10.03.2017].

Eurostat 2016a, http://ec.europa.eu/eurostat/tgm/table.do?tab=table\&init=1\&plugin $=1 \&$ pcode $=$ tec00118\&language $=$ en [dostęp: 10.03.2017].

Eurostat, 2016b, http://appsso.eurostat.ec.europa.eu/nui/setupModifyTableLayout.do [dostęp: 17.03.2017].

Eurostat, 2016c, Metodologia obliczania zharmonizowanego wskaźnika cen konsumpcyjnych, http:/osp.stat.gov.lt/documents/10180/586325/SVKI_metodika20140317.pdf [dostęp: 17.03.2017].

Hall R., Taylor J., 2009, Makroekonomia, Wydawnictwo Naukowe PWN, Warszawa.

Kurs dzienny walut na Litwie 1994-2002, http://www.lb.lt/exchange/default.asp [dostęp: 17.03.2017].

Marciniak S., 2013, Makro- $i$ mikroekonomia, Wydawnictwo Naukowe PWN, Warszawa.

Miesięczny stosunek lita do zagranicznych walut, 1993-2014, https://www.lb.lt/lt/stat/exchange fact_dayl.html [dostęp: 17.03.2017].

Radom ir palyginom: kainos prieš eurq ir dabar, 2016 (2016.05.03), http://verslas.lrytas.lt/mano-pinigai/radom-ir-palyginom-kainos-pries-eura-ir-dabar.htm [dostęp: 17.03.2017].

Solow M.R., Taylor J., 2002, Inflacja, bezrobocie a polityka monetarna, CeDeWu, Warszawa.

Sprawozdanie Komisji z dnia 16.05.2006, Sprawozdanie o konwergencji z 2006 r. dotyczące Litwy, http://eur-lex.europa.eu/legal-content/PL/TXT/?qid=1479495198597\&uri= CELEX:52006DC0223 [dostęp: 17.03.2017].

Statistical Yearbook of Lithuania 2008, Lietuvos Statistikos Metraštis 2008, 2008, Lietuvos Statistikos Departamentas, Vilnius.

Statistical Yearbook of Lithuania 2010, Lietuvos Statistikos Metraštis 2010, 2010, Lietuvos Statistikos Departamentas, Vilnius.

Statistical Yearbook of Lithuania 2011, Lietuvos Statistikos Metraštis 2011, 2011, Lietuvos Statistikos Departamentas, Vilnius. 
Statistical Yearbook of Lithuania 2013, Lietuvos Statistikos Metraštis 2013, 2013, Lietuvos Statistikos Departamentas, Vilnius.

Statistical Yearbook of Lithuania 2014, Lietuvos Statistikos Metraštis 2014, 2014, Lietuvos Statistikos Departamentas, Vilnius.

Statistical Yearbook of Lithuania 2015, Lietuvos Statistikos Metraštis 2015, 2015, Lietuvos Statistikos Departamentas, Vilnius.

Statistical Yearbook of Lithuania 2016, Lietuvos Statistikos Metraštis 2016, 2016, Lietuvos Statistikos Departamentas, Vilnius.

Szyszko M., 2009, Prognozowanie inflacji w polityce pieniężnej, Wydawnictwo C.H. Beck, Warszawa.

Uchwała Komitetu Lita o wprowadzeniu waluty narodowej i wycofaniu z obiegu talonów z dnia 14 czerwca 1993 roku, https://www.e-tar.lt/portal/lt/legalAct/TAR.2A77859AFFA3 [dostęp: 17.03.2017].

Uchwała rządu Litwy i zarządu Banku Litwy nr 461 z dnia 16 czerwca 1993 roku o zatwierdzeniu porządku i warunków wycofania z obiegu talonów w Litewskiej Republice https://www.e-tar.lt/portal/lt/legalAct/TAR.B446A5B488F4 [dostęp: 17.03.2017].

Uchwała rządu Litwy nr 213 z dnia 30 czerwca 1994 roku O bazowej walucie i ustaleniu kursu Lita, https://www.e-tar.lt/portal/lt/legalAct/TAR.274CB40D4836 [dostęp: 17.03.2017].

Uchwała rządu Litwy nr 1050 z dnia 29 września 2005 roku O zatwierdzeniu planu wprowadzenia euro i strategii informowania ludności, https://eseimas.lrs.lt/portal/lega1Act/lt/TAD/TAIS.262737? positionInSearchResults $=0 \&$ searchModelUUID $=4 \mathrm{c} 89 \mathrm{c} 120$ -f7d7-4f6d-8ecd-13270ad98e32 [dostęp: 17.03.2017].

Uchwała rządu Republiki Litewskiej nr 604 z dnia 26 czerwca 2013 roku O zatwierdzeniu planu wprowadzenia euro i strategii informowania ludności, https://www.e-tar.lt/ portal/1t/legalAct/TAR.113E85AF912F [dostęp: 17.03.2017].

Uchwała Sejmu Republiki Litewskiej z dnia 13 grudnia 2012 roku nr XII-51 O programie rządu Republiki Litewskiej, https://e-seimas.lrs.lt/portal/legalAct/lt/TAD/TAIS.439761 [dostęp: 17.03.2017].

Uchwała Zarządu Banku Litwy nr 60 O oficjalnym kursie lita, https://www.e-tar.lt/portal/ lt/legalAct/TAR.072D61C8E65E [dostęp: 17.03.2017].

Uchwała Zarządu Banku Litwy nr 15 O bazowej walucie i oficjalnym kursie lita z dnia 1 lutego 2002, https://www.e-tar.lt/portal/lt/legalAct/TAR.52C0DE6D1886 [dostęp: 17.11.2016].

Ustawa o pieniądzach Litwy z dnia 1 lipca 1993 roku nr I-199, https://www.e-tar.lt/portal/ 1t/legalAct/TAR.03086D82AE1F [dostęp: 17.03.2017].

Ustawa Sejmu Litwy nr XII-828 z dnia 17 kwietnia 2014 roku, Ustawa o wprowadzeniu euro na Litwie, https://www.e-tar.lt/portal/lt/legalAct/78f45360cf9d11e3a8ded1a0f5aff0a9 [dostęp: 20.03.2017].

Wołkonowski J., 2016, Handel zagraniczny Litwy w latach 2012-2015 a sankcje gospodarcze przeciw Rosji, Prace Naukowe Uniwersytetu Ekonomicznego we Wrocławiu, Polityka Ekonomiczna, nr 450.

World Bank, 2010, http://data.worldbank.org/indicator/FP.CPI.TOTL.ZG?locations=LT\& view $=$ chart [dostęp: 10.03.2017].

World Bank, 2016, http://data.worldbank.org/indicator/NY.GDP.DEFL.KD.ZG?locations=LT\& view $=$ chart [dostęp: 17.05.2017].

J. Wołkonowski (®) wolkonowski@uwb.edu.pl

Uniwersytet w Białymstoku, Wydział Ekonomiczno-Informatyczny w Wilnie, Naugarduko g. 76, Wilno, LT-03202, Litwa 